Aleksandra Mitovski*1, Vesna Grekulović ${ }^{1}$, Nada Štrbac ${ }^{1}$, Sanja Milutinović Jovanović ${ }^{2}$, Kristina Božinović ${ }^{1}$, Milica Zdravković ${ }^{1}$

${ }^{1}$ University of Belgrade, Technical Faculty in Bor, Bor, Serbia

${ }^{2}$ Special Hospital for Non-specific Lung Deseases „Sokobanja“, Sokobanja, Serbia
Pregledni rad

ISSN 0351-9465, E-ISSN 2466-2585

UDC: 604.4:615.33-034.3

https://doi.org/10.5937/zasmat2104297M

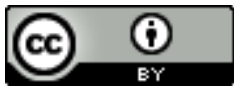

Zastita Materijala 62 (4)

297 - 303 (2021)

\title{
Antimicrobial properties of copper and its alloys through the prism of the current SARS CoV-2 pandemic
}

\begin{abstract}
Copper has long been known as a metal with outstanding antimicrobial properties. Although ancient healers were not familiar with the mechanisms of its influence on microorganisms, they had empirically established its effectiveness in sterilizing drinking water, disinfecting wounds, treating skin diseases, various infections and other maladies. Recently, there has been renewed interest in investigating copper and its alloys as possible materials that can limit the spread of bacteria and viruses, given that humanity is often facing various local epidemics, and rarely pandemics, as ongoing Corona virus, SARS CoV-2, first detected in March 2020. This paper reviews the recent literature in the research field of antimicrobial properties of metallic copper, its alloys and other copper - based materials, with the aim to promote their future implementation on contact surfaces, primarily in hospitals and institutions with a high frequency of people where the probability of spreading infection is increased.
\end{abstract}

Keywords: biocidal properties, copper, contact killing, microbes, SARS CoV-2.

\section{INTRODUCTION}

Copper is one of the first metals known to human civilization, which was, due to its discovery in the native form, used 10.000 years ago in Western Asia. In the area of Mesopotamia, 5.000 years ago, copper extraction techniques were first mastered using smelting, casting and forging, and about 1.000 years later, copper smelting from complex copper ores with arsenic, antimony and lead began. Production of bronze, copper alloy with tin, started during $2500-2200$ BC [1]. The application of copper during the industrial revolution took an abrupt upward trajectory, where it found a wide range of applications, only to be later suppressed by new cheaper materials such as plastic, tempered glass, aluminium and steel.

Copper and its alloys, due to their unique physical, mechanical, thermal and electrical properties, are nowadays widely used in many areas of industry and economy and are the subject of continuous interest of numerous researchers.

\footnotetext{
${ }^{*}$ Corresponding author: Aleksandra Mitovski

E-mail: amitovski@tfbor.bg.ac.rs

Paper received: 21. 07. 2021.

Paper corrected: 01. 09. 2021.

Paper accepted: 13. 09. 2021.

Paper is available on the website: www.idk.org.rs/journal
}

Copper, in various forms, has been attracting attention in recent decades because of its extraordinary antimicrobial properties, which were well known to the ancient Egyptians, Greeks, Romans and Aztecs. From the ancient times, healers recognized the important role of copper in the treatment and maintenance of good health, although at that time they did not have the knowledge about the reaction mechanisms on microorganisms. In one of the oldest medical writings in the history of mankind dated 1600 BC, known as Smith papyrus, states that copper was used to sterilize drinking water and disinfect wounds [2,3]. In the Ebers papyrus from about $1550 \mathrm{BC}$ the use of copper is recommended in the form of metal shavings, natural salts and oxides for the treatment of limb tremors (probably epilepsy), skin diseases and burns [4]. Aztec civilization used copper for medical purposes, including rinsing the throat with copper-infused water against inflammation and infection. In ancient India and Egypt, it was used to make storing vessels for drinking water [5]. Copper was also used for medical purposes in the ancient Greece and Rome, in order to treat lung diseases, eye infections and disinfect fresh wounds. In Writings of Hippocrates [2], it was recommended to sprinkle fresh wounds with a mixture of dry powder of copper oxide and copper sulfate and to coat it with a mixture of honey and red copper oxide. 
Copper played a significant role in the history of health even in the New Era. During the cholera epidemic in Paris in the XIX century, physicians discovered that workers in copper smelters were almost immune to cholera, while a vast number of the surrounding population succumbed to the disease [6]. During the second half of the XIX century, European physicians recommended the use of copper to treat arthritis, diarrhea, dysentery, and tuberculosis. Even in the XX century, copper still played an important role in the history of human health. The use of copper as an antimicrobial agent continued until the discovery of commercially available antibiotics in 1932. In 1939, German medical researchers discovered that workers in copper mines and smelters did not suffer from arthritis during their active working in those facilities. This observation led researchers to use copper to treat arthritis, fever, sciatica, neck and back pain [2]. Recently there has been an assumption that the heart attack rate in France is the lowest of all European countries due to significantly higher consumption of red wine by the French, which has a higher copper content than white wine $[7,8]$. The spread of antibiotic resistance has led to the emergence of antibiotic-resistant bacteria, frequently present in hospitals, nursing homes, food processing plants and commercial animal farms. This has triggered the need for different approaches and research to keep these pathogenic microorganisms under control. One of the alternatives is the use of copper surfaces in hygienically sensitive buildings [9].

Kuhn's research [10], as one of the first in this field, confirmed the positive influence of brass handles in order to reduce some bacterial cultures from different hospital areas. The clinical trial included monitoring the growth of the so-called "hospital" bacteria such as Escherichia coli, Staphylococcus aureus, Streptococcus group D and Pseudomonas on stainless steel, brass, aluminium and copper. The results showed that the growth of bacteria on copper and brass surface was almost completely stopped, with the effect of brass self-cleaning being achieved in a maximum of 7 hours, while copper self-disinfected in $15 \mathrm{~min}$ from some microbial species. On the other hand, steel and aluminium surfaces showed intensive growth of all tested bacteria in the next 8 days, while some bacteria were still present in the next 3 weeks. Despite the outstanding results, this research went unnoticed. Only recently there has been more intense interest in the use of copper as a self-disinfecting material, with the focus of research on the mechanism of copper influence on the so-called "contact killing" of pathogens [11].

Sudha et al. [12] investigated the effect of storing drinking water in a copper vessels, microbiologically contaminated with bacteria that cause diarrhea. The results of the study revealed that none of the tested pathogens survived in drinking water stored in copper vessels, even after enrichment with bacterial cultures. This study confirmed the knowledge of ancient healers that copper indeed has got the amazing health properties.

\section{MECHANISMS OF ANTIBACTERIAL ACTION OF COPPER}

The toxic effect of copper on microorganisms was used in agriculture to control bacterial and fungal plant diseases [13], which later led to the first detailed studies of the biocidal properties of copper [14]. The study of antimicrobial properties of copper surfaces has recently been more intensively developed, especially since 2008 when the US Environmental Protection Agency registered almost 300 different copper-based surfaces as antimicrobial [15].

The molecular mechanisms of antibacterial activity of copper are the result of its atomic structure, especially the outer electron shell, as well as the pronounced ability of metallic copper to easily be an electron donor or acceptor, which is a characteristic of elements with high electrochemical potential. Many useful properties of copper are based on these properties, including its electrochemical properties used in biological systems [16]. Thanks to the electrochemical potential, the free copper ion interacts with bacterial proteins, which results in the suppression of their activity, and gives copper its antibacterial character. The antibacterial mechanism is very complex and can take place both within cells and in the intercellular space [17].

Although the mechanism of the biocidal activity of copper has not yet been sufficiently explained, it is currently accepted that the mechanism of the antibacterial action of copper and the contact killing of pathogenic microorganisms includes the following key steps:

1. The increased concentration of copper inside cells leads to oxidative stress, i.e. the lack of balance between the activity of reactive oxygen species and the biological ability to quickly detoxify reactive by-products or repair damage, resulting in the formation of hydrogen peroxide. In these cellular conditions, copper participates in the socalled Fenton-type reaction [18,19]:

$$
\mathrm{Cu}^{+}+\mathrm{H}_{2} \mathrm{O}_{2} \rightarrow \mathrm{Cu}^{2+}+\mathrm{OH}^{-}+\mathrm{OH}^{-}
$$

which in combination with the reactions of the Haber - Weiss cycle [20]:

$$
\mathrm{H}_{2} \mathrm{O}_{2}+\mathrm{OH}^{\cdot} \quad, . \mathrm{I}_{2} \mathrm{O}+\mathrm{O}_{2}^{-}+\mathrm{H}^{+}
$$




$$
\mathrm{H}_{2} \mathrm{O}_{2}+\mathrm{O}_{2}^{-} \rightarrow \mathrm{O}_{2}+\mathrm{OH}^{-}+\mathrm{OH}^{\cdot}
$$

provides a rich source of reactive oxygen species that produce large amounts of hydrogen peroxide. Hydrogen peroxide acts as a catalyst for the formation of highly reactive hydroxyl radicals that lead to irreversible oxidative damage to cellular parts of pathogenic microorganisms [21]. The formation of reactive radicals is probably mediated by the redox cycle between different ionic types of copper: $\mathrm{Cu}^{0}, \mathrm{Cu}^{+} \mathrm{i} \mathrm{Cu}^{2+}[22]$.

2. Excess copper leads to damage to the microorganisms cell membrane, resulting in "leakage" of nutrients, which causes the cell to dry out and die [23].

3. Although copper is necessary for many reactions that take place in proteins, in higher concentrations copper binds to proteins that do not require its presence to function. This improper binding leads to atrophy of protein functions and their breakdown into dysfunctional components [17].

Some studies [24-27] on the mechanism and kinetics of contact killing during exposure of bacteria to copper and copper alloy surfaces have generally shown that microbes, depending on type, are inactivated in an interval of several hours, with higher copper content in the alloy, elevated temperature and relative humidity increasing the efficiency of the contact killing process [28-30]. Comparative studies of the microorganisms contact killing kinetics using dry and wet inoculation techniques have shown that dry and clean copper surfaces have better antimicrobial properties, which opens new questions in the research of contact killing mechanisms [31-33]. Table 1 summarizes some of the results of various investigations of contact killing kinetics of different types of microbes on the surfaces of copper and its alloys.

Table 1. Contact killing time of some of the microbes on copper surfaces

Tabela 1. Vreme kontaktnog ubijanja nekih mikroba na bakarnim površinama

\begin{tabular}{|l|c|c|}
\hline \multicolumn{1}{|c|}{ Microbe species } & $\begin{array}{c}\text { Contact killing } \\
\text { time at room } \\
\text { temperature }\end{array}$ & Reference \\
\hline Salmonella enterica & $4 \mathrm{~h}$ & {$[27]$} \\
\hline Escherichia coli & $65-75 \mathrm{~min}$ & {$[34,34]$} \\
\hline MRSA & $45-180 \mathrm{~min}$ & {$[25,35]$} \\
\hline $\begin{array}{l}\text { Influenza A virus } \\
\text { (H1N1) }\end{array}$ & $6 \mathrm{~h}$ & {$[36]$} \\
\hline $\begin{array}{l}\text { Mycobacterium } \\
\text { tuberculosis }\end{array}$ & $5-15$ days & {$[35]$} \\
\hline Candida albicans & $60 \mathrm{~min}$ & {$[35]$} \\
\hline Enterococcus hirae & $90 \mathrm{~min}$ & {$[37]$} \\
\hline
\end{tabular}

\section{ANTIMICROBIAL PROPERTIES OF COPPER AND ITS ALLOYS}

In institutions like hospitals and in places with a large daily people fluctuation, bus and train stations, airports, large shopping centres, etc, there are many areas that are frequently touched (handles, handrails, ATMs, coffee machines, trays, bells, bed racks, toilet chairs, etc). These areas which are made of plastic, aluminium or stainless steel, can be significantly contaminated with bacteria and fungi. It is estimated that about $80 \%$ of infectious diseases are transmitted by contact. Infectious microbes can survive on the surfaces in hospital conditions from a few days to as many as a few months, with which staff, patients and visitors can come into contact and endanger their health [32]. The most common infections in hospitals are methicillin-resistant Staphilococcus aureus (MRSA), coli bacillus as Escherichia coli, Klebsiella pneumoniae and Clostridium difficile. Frequent and efficient cleaning, in combination with proper hand hygiene, reduces the transmission of infections, but complete removal of pathogenic microorganisms is practically impossible [38]. The global spread of resistant bacteria has led to dangerous nosocomial infections that claim tens of thousands of lives each year and further increase hospital costs, measured in billions of dollars [39]. Stainless steel is mostly used in healthcare facilities due to its shiny aesthetic appearance and high corrosion stability. However, its use does not have a significant antimicrobial advantage over copper [40]. Copper surfaces, with their self-disinfecting properties, could contribute to controlling the spread of infections by reducing surface contamination, as evidenced by in-hospital testing $[41,42]$.

Montero et al. [43] performed an antimicrobial characterization of a new composite material called "Copper Armor", in which copper particles are evenly distributed in the methyl methacrylate matrix, and always partially exposed to the surface. The bactericidal effect of this self-disinfecting composite against dangerous human pathogens and a significant reduction in the concentration of microbes on hospital surfaces have been confirmed. Therefore, there is a need for new approaches to hygiene in hospitals, where copper, its alloys and new copper-based composites, with their proven antimicrobial properties, need to be considered as an addition to existing hygiene measures, which is estimated to reduce infections by about $15 \%$ per year [36].

Copper has a powerful ability to neutralize infectious viruses such as bronchitis virus, poliovirus, human immunodeficiency virus (HIV-1), norovirus and other unilateral or bilateral DNA and RNA viruses [44]. One of the causes of high speed 
transmission of respiratory viruses is related to their ability to survive on dry surfaces. On various surfaces for everyday use, such as ceramic tiles, teflon, PVC, glass, rubber and stainless steel, human corona virus $\mathrm{HCoV} 229 \mathrm{E}$ remains contagious for at least 5 days, which is long enough to touch the surface contaminated with respiratory droplets and further spread the virus. However, when HCoV 229E comes in contact with a copper or brass surface, its viral genomes and morphology become irreversibly damaged after 10 minutes of exposure [45]. Kampf et al. [46] found that, depending on the contact surface, SARS and MERS coronaviruses, as well as $\mathrm{HCoV}$, can be contagious for up to 9 days at room temperature and up to 28 days at $4{ }^{\circ} \mathrm{C}$, respectively. Human coronavirus is rapidly inactivated on a number of copper alloys. Brass has been shown to be very effective at lower $\mathrm{Cu}$ concentrations, with $\mathrm{Cu}^{+}$and $\mathrm{Cu}^{2+}$ ions participating in virus inactivation, which is enhanced by the formation of reactive oxygen species on alloy surfaces. The newly descovered coronavirus, SARS-CoV-2, responsible for the ongoing COVID-19 pandemic, is proven to be very sensitive to contact with the copper surface $[47,48]$.

In order to prevent the spread of the SARSCoV-2 virus, the US Environmental Protection Agency registered a group of antimicrobial copper alloys with $92.6 \% \mathrm{Cu}$ and $3.8 \%$ of other elements in February 2021. These alloys are intended only for the production of contact surface components for use in hospitals, healthcare facilities, laboratories and various public, commercial and residential buildings. Experimental investigation of this group of alloys showed that $99.9 \%$ of grampositive and gram-negative bacteria are inactivated within $2 \mathrm{~h}$ of exposure (Staphylococcus aureus, Enterobacter aerogenes, Methicillin-Resistant Staphylococcus aureus-MRSA, Escherichia coli 0157:H7, Pseudomonas aeruginosa Vancomycin-Resistant Enterococcus faecalisVRE) and viruses (Human coronavirus-229E, Rhinovirus Type 37 i Rotavirus Strain WA.), if these surfaces are regularly disinfected $[49,50]$.

Borkov et al. [51] showed that impregnation with copper oxide in protective respiratory face masks shows biocidal properties against influenza $A$ virus, without changing the characteristics of the physical barrier. Hang et al. [52] determined the antiviral effect of copper oxide nanoparticles against hepatitis $\mathrm{C}$ virus ( $\mathrm{HCV}$ ).

\section{ANTIMICROBIAL PROPERTIES OF OTHER METALS AND ALLOYS}

Research on the antibacterial properties of 21 metals (except iron) showed that copper and silver had similar degrees of contact killing efficiency, 5-
10 times higher than the values of other tested metals [53]. Silver has been known for a long time as an antibacterial metal and is already widely used as an antibacterial agent, mainly in colloidal form, because only in this state silver has the ability to release ions [54]. Although the silver cation is more toxic to bacteria than the copper cation [55], silver is unstable in the $\mathrm{Ag}^{2+}$ oxidation state and does not catalyze Fenton-type reactions. It was found, as a result of research by Mikolay et al. [30], that silver surfaces do not kill bacteria, which confirms that copper alloys are indeed much more bactericidal than materials containing silver.

Using the method of atomic force microscopy, Nan et al. [56] showed that antibacterial steel (stainless steel with $3.8 \% \mathrm{Cu}$ ) destroyed the cell membrane and/or bacterial cell wall and increased cell permeability, while on control steel the cells remained intact. Their research also confirmed that the adhesion of bacteria to antibacterial stainless steel was significantly higher than one performed on control steel, which is explained by the effect of released $\mathrm{Cu}^{2+}$ ions. These findings highlight new aspects of contact killing that can be applied to other antimicrobial surfaces. The importance of contact between bacteria and metals in contact killing further supports the observation that strong contamination of the copper surface significantly reduces the effect of contact killing [57]. Santo et al. [22] found that $76 \%$ of bacteria isolated from Euro currency coins $(25 \% \mathrm{Ni}$ and $75 \% \mathrm{Cu}$, alloys with pronounced antibacterial activity) are still susceptible to contact killing when applied to a copper surface. It is assumed that these bacteria survived on the coins only due to the surface contamination.

Recently, the influence of different metal coatings (Co, $\mathrm{Zn}, \mathrm{Cu}$ and cobalt alloys with $\mathrm{Ni}, \mathrm{Zn}$, $\mathrm{Cr}$ ) on the inhibition of growth of some pathogenic gram-positive and gram-negative bacteria was investigated. The inhibitory effect of the coating was found to be directly related to the amount of produced $\mathrm{H}_{2} \mathrm{O}_{2}$ [58]. Despite the already wellknown biocidal efficiency of copper, healthcare institutions and industry continue to produce furniture and equipment using polymers and stainless steel that are cheaper than copper and its alloys. At the same time, many industries use thermal spraying procedures to apply coatings to protect the substrate from wear, heat or corrosion [59]. This technology is also one of the costeffective applications of copper for the purpose of effectively reducing bacterial contamination on contact surfaces. It needs to be taken into consideration for the copper based antimicrobial materials production in the future. 


\section{CONCLUSION}

The main purpose of this review paper is to raise awareness of the general public and the economy about the importance of copper and its alloys as a powerful weapon in the fight against pathogenic microorganisms and potentially deadly viruses, such as the ongoing Corona virus (SARSCoV-2). The plagues of pandemics that periodically throw human civilization out of the normal course of life, often resulting in millions of victims and collapse of the global economy, should lead us already not only to think, but also to intensify the activities to prevent the spreading of dangerous bacteria and viruses. One of them is certainly much higher prevalence of copper and its alloys, as well as new copper-based materials in healthcare facilities, as a complementary strategy that can help reduce bacterial concentrations and viral load. The medical legacy left to us by ancient civilizations can now be combined with modern science to discover new biocidal materials and implement them on contact surfaces in places with high human fluctuation in order to reduce the spread of infections, decrease additional hospital treatment costs and, most importantly, save lives.

\section{Acknowledgement}

The authors are thankful to the Ministry of Education, Science and Technological Development of the Republic of Serbia for financial support in the research conducted at the Technical Faculty in Bor, University of Belgrade (Contract No. 45103-9/2021-14/200131). The contribution of Gordana Mundrić, professor of English language and literature, for proofreading the manuscript, is also greatly appreciated.

\section{REFERENCES}

[1] R.F.Tylecote (1992) History of metallurgy, $2^{\text {nd }} E d$. Maney Publishing, Institute of Materials, London.

[2] H.H.A.Dollwet, J.R.J.Sorenson (1985) Historic uses of copper compounds in medicine, Trace Elements in Medicine, 2(2), 80-87.

[3] S.M.Arab (2017) Medicine in ancient Egypt, Arab World Books (https://www.arabworldbooks.com/ en/e-zine/medicine-in-ancient-egypt-part-3-of-3, 15.03.2021.)

[4] J.F.Nunn (2003) Ancient Egyptian Medicine, The British Museum Press, London.

[5] G.Borkow, J.Gabbay (2005) Copper as a biocidal tool, Current Medicinal Chemistry, 12, 2163-2175.

[6] O.Walusinski (2018) The scientific illusion of Victor Burq (1822-1884), European Neurology, 79, 135149.

[7] M.Grønbæk, U.Becker, D.Johansen, A Gottschau, P. Schnohr, H.O.Hein, G.B.Jensen, T.I.A. Sorensen (2000) Type of alcohol consumed and mortality from all causes, coronary heart disease, and cancer, Annals of Internal Medicine, 133, 411-419.
[8] I.Suh, J.Shaten, J.A.Cutler, L.H.Kuller (1992) Alcohol use and mortality from coronary heart disease: the role of high-density lipoprotein cholesterol, Annals of Internal Medicine, 116, 881-887.

[9] R.J.Dick, J.A.Wray, H.N.Johnston (1973) A literature and technology search on the bacteriostatic and sanitizing properties of copper and copper alloy surfaces, Battelle Columbus Laboratories, Columbus, Ohio, USA.

[10] P.J.Kuhn (1983) Doorknobs: A Source of Nosocomial Infection?, Diagnostic Medicine, 1-2.

[11] G.Grass, C.Rensing, M.Solioz (2011) Metallic Copper as Antimicrobial Surface, Applied and Environmental Microbiology, 77(5), 1541-1547.

[12] V.B.P.Sudha, S.Ganesan, G.P.Pazhani, T. Ramamurthy, G.B.Nair, P.Venkatasubramanian (2012) Storing Drinking-water in Copper pots Kills Contaminating Diarrhoeagenic Bacteria, Journal of Health, Population and Nutrition, 30(1), 17-21.

[13] J.R.Lamichhane, E.Osdaghi, F.Behlau, J.Köhl, J.B.Jones, J-N.Aubertot (2018) Thirteen decades of antimicrobial copper compounds applied in agriculture. A review, Agronomy for Sustainable Development, 38, e.28.

[14] D.A.Cooksey (1994) Molecular mechanisms of copper resistance and accumulation in bacteria, FEMS Microbiology Reviews, 14, 381-386.

[15] Copper Development Association Inc. (https://www.copper.org/about/pressreleases/2008/ pr2008_Mar_25.html, 18.03.2021.)

[16] A.Lewis, C.W.Keevil (2004) Antibacterial properties of alloys and its alloys in HVAC\&R systems, International Copper Association, New York, USA.

[17] R.B.Thurman, C.P.Gerba (1989) The Molecular Mechanisms of Copper and Silver Ion Disinfection of Bacteria and Viruses, CRC Critical Reviews in Environmental Control, 18(4), 295-315.

[18] X.Liu, Y.Sang, H.Yin, A.Lin, Z.Guo, Z.Liu (2018) Progress in the Mechanism and Kinetics of Fenton Reaction, Ecology \& Environmental Sciences, 3 (1), 10-15.

[19] A.N.Pham, G.Xing, C.J.Miller, T.D.Waite (2013) Fenton-like copper redox chemistry revisited: Hydrogen peroxide and superoxide mediation of copper-catalyzed oxidant production, Journal of Catalysis, 301, 54-64.

[20] M.Baureder, R.Reimann, L.Hederstedt (2012) Contribution of catalase to hydrogen peroxide resistance in Enterococcus faecalis, FEMS Microbiology Letters, 331, 160-164.

[21] S.Mathews, M.Hans, F.Mücklich, M.Solioz (2013) Contact Killing of Bacteria on Copper Is Suppressed if Bacterial-Metal Contact Is Prevented and Is Induced on Iron by Copper Ions, Applied and Environmental Microbiology, 79(8), 2605-2611.

[22] C.E.Santo, P.V.Morais, G.Grass (2010) Isolation and characterization of bacteria resistant to metallic copper surfaces, Applied and Environmental Microbiology, 76, 1341-1348.

[23] J.Konieczny, Z.Rdzawski (2012) Antibacterial properties of copper and its alloys, Archives of Materials Science and Engineering, 56(2), 53-60. 
[24] D.Quaranta, T.Krans, C.Espírito Santo, C.G. Elowsky, D.W.Domaille, C.J.Chang, G.Grass, (2011) Mechanisms of contact-mediated killing of yeast cells on dry metallic copper surfaces, Applied and Environmental Microbiology, 77, 416-426.

[25] J.O.Noyce, H.Michels, C.W. Keevil (2006) Potential use of copper surfaces to reduce survival of epidemic meticillin-resistant Staphylococcus aureus in the healthcare environment, Journal of Hospital Infection, 63, 289-297.

[26] S.A.Wilks, H.Michels, C.W.Keevil (2005) The survival of Escherichia coli 0157 on a range of metal surfaces. International Journal of Food Microbiology, 105, 445-454.

[27] G.Faundez, M.Troncoso, P.Navarrete, G.Figueroa (2004) Antimicrobial activity of copper surfaces against suspensions of Salmonella enterica and Campylobacter jejuni, BMC Microbiol., 4(19), 1-7.

[28] J.Elguindi, S.Moffitt, H.Hasman, C.Andrade, S.Raghavan, C.Rensing (2011) Metallic copper corrosion rates, moisture content, and growth medium influence survival of copper-resistant bacteria, Applied Microbiology and Biotechnology, 89(6), 1963-1970.

[29] H.T.Michels, J.O.Noyce, C.W.Keevil (2009) Effects of temperature and humidity on the efficacy of methicillin-resistant Staphylococcus aureus challenged antimicrobial materials containing silver and copper, Letters in Applied Microbiology, 49, 191-195

[30] A.Mikolay, S.Huggett, L.Tikana, G.Grass, J.Braun, D.H.Nies (2010) Survival of bacteria on metallic copper surfaces in a hospital trial, Applied Microbiology and Biotechnology, 87, 1875-1879.

[31] C.E.Santo, N.Taudte, D.H.Nies, G.Grass (2008) Contribution of copper ion resistance to survival of Escherichia coli on metallic copper surfaces, Applied and Environmental Microbiology, 74, 977986.

[32] A.Kramer, I.Schwebke, G.Kampf (2006) How long do nosocomial pathogens persist on inanimate surfaces? A systematic review, BMC Infectious Diseases, 6, 130-138.

[33] C.E.Santo, E.W.Lam, C.G.Elowsky, D.Quaranta, D.W.Domaille, C.J. Chang, G.Grass (2011) Bacterial killing by dry metallic copper surfaces, Applied and Enviromental Microbiology, 77, 794802.

[34] [34] J.O.Noyce, H.Michels, C.W.Keevil (2006) Use of copper cast alloys to control Escherichia coli 0157 cross-contamination during food processing, Appled and Environmental Microbiology, 72, 42394244.

[35] S.Mehtar, I.Wiid, S.D.Todorov (2008) The antimicrobial activity of copper and copper alloys against nosocomial pathogens and Mycobacterium tuberculosis isolated from healthcare facilities in the Western Cape: an invitro study, Journal of Hospital Infection, 68, 45-51.

[36] J.O.Noyce, H.Michels, C.W.Keevil (2007) Inactivation of influenza A virus on copper versus stainless steel surfaces, Applied and Environmental Microbiology, 73, 2748-2750.
[37] C.Molteni, H.K.Abicht, M.Solioz (2010) Killing of bacteria by copper surfaces involves dissolved copper, Applied and Environmental Microbiology, 76, 4099-4101.

[38] S.J.Dancer (2008) Importance of the environment in meticillin-resistant Staphylococcus aureus acquisition: the case for hospital cleaning, Lancet Infectious Diseases, 8, 101-113.

[39] Centers for Desease Control and Prevention (https://arpsp.cdc.gov/profile/antibioticresistance?tab=antibiotic-resistance, 08.04.2021.)

[40] H.D.Kusumaningrum, G.Riboldi, W.C.Hazeleger, R.R.Beumer (2003) Survival of foodborne pathogens on stainless steel surfaces and crosscontamination to foods, International Journal of Food Microbiology, 85, 227-236.

[41] A.L.Casey, D.Adams, T.J.Karpanen, P.A.Lambert, B.D. Cookson, P.Nightingale, L.Miruszenko, R. Shillam, P.Christian, T.S.J.Elliott (2010) Role of copper in reducing hospital environment contamination, Journal of Hospital Infection, 74, 72-77.

[42] F.Marais, S.Mehtar, L.Chalkley (2010) Antimicrobial efficacy of copper touch surfaces in reducing environmental bioburden in a South African community healthcare facility, Journal of Hospital Infection, 74, 80-82.

[43] D.A.Montero, C.Arellano, M.Pardo, R.Vera, R. Gálvez, M.Cifuentes, M.A.Berasain, M.Gómez, C.Ramírez, R.M.Vidal (2019) Antimicrobial properties of a novel copperbased composite coating with potential for use in healthcare facilities, Antimicrobial Resistance and Infection Control, 8(3), 1-10.

[44] J.L.Sagripanti L.B.Routson C.D.Lytle (1993) Virus inactivation by copper or iron ions alone and in the presence of peroxide, Applied and Environmental Microbiology, 59, 4374-4376.

[45] S.L.Warnes, Z.R.Little, C.W.Keevil (2015) Human coronavirus 229E remains infectious on common touch surface materials, MBio, 6(6), e01697-01615.

[46] G.Kampf, D.Todt, S.Pfaender, E.Steinmann (2020) Persistence of coronaviruses on inanimate surfaces and their inactivation with biocidal agents, Journal of Hospital Infection, 104(3), 246-251.

[47] N. van Doremalen, T.Bushmaker, D.H.Morris, M.G.Holbrook, A.Gamble, B.N.Williamson, A.Tamin, J.L.Harcourt, N.J.Thornburg, S.I.Gerber, J.O.LloydSmith, E. de Wit, V.J.Munster (2020) Aerosol and surface stability of SARS-CoV-2 as compared with SARS-CoV-1, The New England Journal of Medicine, 382(16), 1564-1567.

[48] A.A.Cortes, J.M.Zuniga (2020) The use of copper to help prevent transmission of SARS-coronavirus and influenza viruses, A general review, Diagnostic Microbiology and Infectious Disease, 98(4), 115176.

[49] US Environmental Protection Agency (https://www.epa.gov/newsreleases/epa-registerscopper-surfaces-residual-use-against-coronavirus, 21.04.2021.)

[50] US Environmental Protection Agency (https://www3.epa.gov/pesticides/chem_search/ppls /082012-00001-20210110.pdf, 02.04.2021.) 
[51] G.Borkow, S.S.Zhou, T.Page, J. Gabbay (2010) A novel anti-influenza copper oxide containing respiratory face mask, PLoS ONE, 5, e11295.

[52] X.Hang, H.Peng, H.Song, Z.Qi, X.Miao, W.Xu (2015) Antiviral activity of cuprous oxide nanoparticles against hepatitis $C$ virus in vitro, Journal of Virological Methods, 222, 150-157.

[53] H.Kawakami, K.Yoshida, Y.Nishida, Y.Kikuchi, Y.Sato (2008) Antibacterial properties of metallic elements for alloying evaluated with application of JIS Z 2801:2000, ISIJ International, 48, 1299-1304.

[54] J.Diaz-Visurraga, C.Gutiérrez, C. von Plessing, A.Garcia (2012) Metal nanostructures as antibacterial agents, In A.Méndez-Vilas (ed), Science against microbial pathogens: communicating current research and technological advances, Formatex, Badajoz, Spain, p.210-218.

[55] D.H.Nies (1999) Microbial heavy metal resistance, Applied Microbiology and Biotechnology, 51(6), 730-750.
[56] L.Nan, Y.Liu, M.Lu, K.Yang (2008) Study on antibacterial mechanism of copper-bearing austenitic antibacterial stainless steel by atomic force microscopy, Journal of Materials Science: Materials in Medicine, 19, 3057-3062.

[57] P.Airey, J.Verran (2007) Potential use of copper as a hygienic surface; problems associated with cumulative soiling and cleaning, Journal of Hospital Infection, 67, 272-278.

[58] Z.H.Zhao, Y.Sakagami, T.Osaka (1998) Toxicity of hydrogen peroxide produced by electroplated coatings to pathogenic bacteria, Canadian Journal of Microbiology, 44(5), 441-447.

[59] H.Herman, R.A.Sulit (1993) Thermal Spray Coatings, Welding, Brazing, and Soldering, D.L. Olson, T.A. Siewert, S. Liu, G.R. Edwards (Eds.) Vol. 6. ASM Handbook. Materials Park, Ohio, USA.

\title{
IZVOD
}

\section{ANTIMIKROBNA SVOJSTVA BAKRA I NJEGOVIH LEGURA KROZ PRIZMU AKTUELNE PANDEMIJE SARS COV-2}

\begin{abstract}
Bakar je od davnina poznat kao metal sa izvanrednim antimikrobnim karakteristikama. lako drevni iscelitelji nisu poznavali mehanizme njegovog delovanja na mikroorganizme, iskustveno su ustanovili njegovu efikasnost u sterilizaciji vode za piće, dezinfekciji rana, lečenju kožnih oboljenja, različitih infekcija $i$ drugih bolesti. $U$ novije vreme se ponovo javlja interesovanje za ispitivanje bakra i njegovih legura kao mogućih materijala koji mogu ograničiti širenje bakterija $i$ virusa, $s$ obzirom da se čovečanstvo učestalo suočava sa različitim epidemijama lokalnog karaktera, a povremeno, kao od marta 2020. godine, sa pandemijom korona virusa SARS CoV-2. U radu je dat pregled novije literature $u$ istraživanju antimikrobnih svojstava bakra, njegovih legura $i$ drugih materijala na bazi bakra, u cilju buduće implementacije na dodirnim površinama prvenstveno $u$ bolnicama i ustanovama sa visokom frekvencijom ljudi gde je povećana verovatnoća širenja zaraze.
\end{abstract}

Ključne reči: biocidna svojstva, bakar, kontaktno ubijanje, mikrobi, SARS CoV-2.

Naučni rad

Rad primljen: 21. 07. 2021.

Rad korigovan: 01. 09. 2021.

Rad prihvaćen: 13. 09. 2021.

Rad je dostupan na sajtu: www.idk.org.rs/casopis

(c) 2021 Authors. Published by Engineering Society for Corrosion. This article is an open access article distributed under the terms and conditions of the Creative Commons Attribution 4.0 International license (https://creativecommons.org/licenses/by/4.0/) 